\title{
Resonancias orientales en la obra de Juan Navarro Baldeweg. La vuelta de Hiroshige
}

RODRÍGUEZ LLERA, Ramón

Universidad de Valladolid, 2015

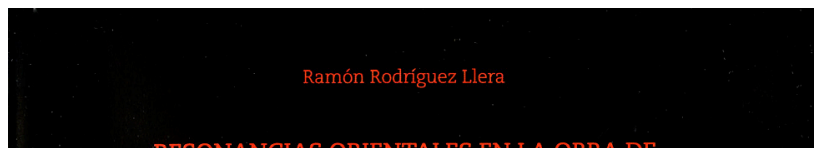

RESONANCIAS ORIENTALES EN LA OBRA DE JUAN NAVARRO BALDEWEG

La vuelta de Hiroshige

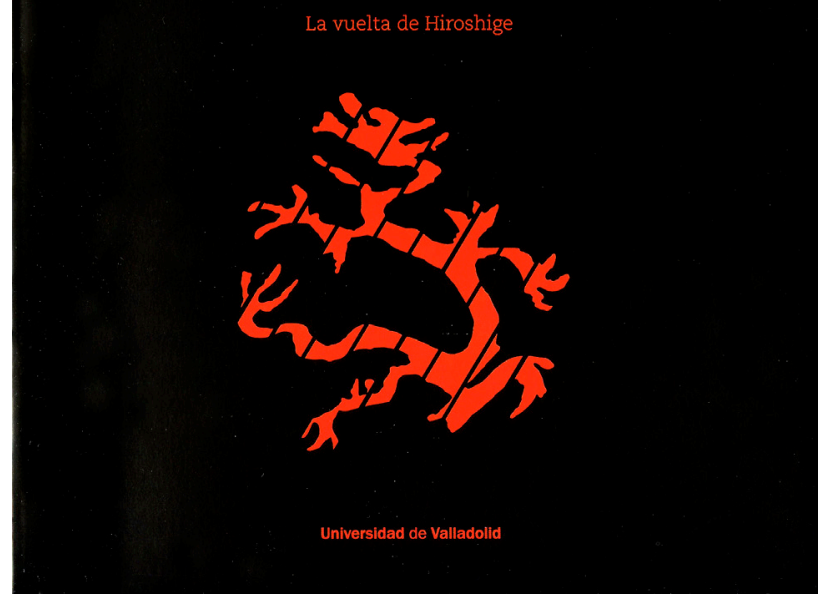

A estas alturas, la incansable labor investigadora de Ramón Rodríguez Llera (Santander, 1955) nos sigue sorprendiendo. Después de la publicación de Japón en Occidente. Arquitecturas y paisajes del imaginario japonés, del exotismo a la modernidad (2013), obra en la que estudia los intercambios culturales entre la arquitectura occidental y la japonesa desde el despertar del Japón moderno en época Meiji hasta nuestros días, nos descubre Resonancias Orientales en la obra de Juan Navarro Baldeweg. La vuelta de Hiroshige (2015), texto en el que investiga el modo en que dicho despertar trasvasa las ideas de la caligrafía a la abstracción, del arte a la arquitectura, de la tradición a la modernidad, de Oriente a Occidente, y viceversa, ecos del proceso creativo de una extensa nómina de artistas y arquitectos entre los que Juan Navarro Baldeweg sobresale con identidad propia.

El libro constituye un lúcido discurso que matiza la dicotomía Oriente-Occidente, dos orillas entre las que tiende puentes de ida y vuelta que se cruzan de manera elocuente con los intereses artísticos de Juan Navarro Baldeweg, verdadero hilo conductor del texto.

El autor fija su mirada en los nuevos cauces de expresión que los maestros calígrafos japoneses, especialmente el pionero Hidai Tenrai, abren hacia las tendencias occidentales de la pintura abstracta como catarsis de su propia tradición. Abstracción e Identidad son las vías por las que discurre el estilo bokushou, "la imagen de la tinta», poniendo el acento en el sincretismo que se da entre caligrafía secular sho, pintura sumi-e y arte abstracto contemporáneo, sobre todo en lo referido al Action Painting, manifestaciones artísticas donde la participación activa del cuerpo y la acción del pincel subrayan el valor de lo expresivo, la energía de lo individual.

Expresionistas abstractos y pintores calígrafos, a uno y otro lado del Océano Pacífico, comparten con Juan Navarro Baldeweg el propósito de volcarse con toda la intensidad del cuerpo y la mano sobre la acción de su pintura. Como entre dos espejos enfrentados que se miran y multiplican la realidad en imágenes especulares, el libro nos conduce de manera brillante desde los grupos de la vanguardia artística japonesa del siglo XX, Sosaku Hanga o Gutai, entre otros, al expresionismo abstracto norteamericano; de los dragones de oro de Shiryu Morita, de los enso performativos de Jiro Yoshihara, de la fuerza de la caligrafía radical de Inoue Yu-chi, autores que anteponen la expresividad a los usos tradicionales del arte oriental como medio para alcanzar la abstracción, al reflejo de las tradiciones artísticas niponas en autores como Mark Tobey o Franz Kline, entusiastas e interesados de un modo más o menos confeso por la filosofía zen y el arte del Shodo.

El libro nos muestra La vertiente hispana de este juego óptico, representada por Juan Navarro Baldeweg en el papel de quien se aventura a cruzar el espacio entre ambos espejos y se observa multiplicado en ellos. Sus años de 
formación con György Kepes en el MIT entre 1971 y 1975 suponen un tiempo de inmersión cultural y artística, el acercamiento a las vanguardias plásticas norteamericanas, al expresionismo abstracto y al minimalismo, y el interés por el arte nipón a partes iguales. La pervivencia de los orígenes en su obra pictórica no escapa al análisis inteligente del autor, que pone el foco en conferencias como Ex Oriente Lux, presenciada en la Universidad de Valladolid en octubre de 2011. Nos desvela paralelismos sorprendentes, como el que relaciona un Kosode japonés decorado con caracteres caligráficos de época Edo, perteneciente al Museo Nacional de Tokio, con la pintura La danza (2007) del arquitecto santanderino, o su admiración hacia Ando Hiroshige, ilustre dignatario del «mundo flotante, del arte del ukiyoe», sin perjuicio del elenco de referencias que nutren con riqueza su obra; de Henri Matisse a Constantin Brancusi, de John Soane a Louis Kahn.

Es precisamente La vuelta de Hiroshige la coyuntura que completa el brillante argumento. De la «conciencia indagatoria" de Juan Navarro Baldeweg aflora un interés por explorar los modelos dominantes de representación en el arte contemporáneo, por la búsqueda de expresiones que activen signos fundamentales de lo natural, por lenguajes entre la abstracción y la figuración. Proyectos experimentales -Casa para una intersección (1976)- e instalaciones - La mesa (a partir de 1973)- asocian ideas convergentes aqui- latadas por el autor: "sinergias referidas a la gravedad y a la materia (...) juegos de contrapeso, de levedad, de equilibrio, de tensión estructural, generando espacios dinámicos cargados de significación». Entre ellos subyace filtrado, atendiendo al esclarecedor texto, el modo de Ando Hiroshige de ver el mundo, que «descompone la naturaleza en variables, la disecciona de acuerdo con sus leyes y posibilidades de expresión y la reproduce con medios expresivos diferenciados, heterogéneos, lo que Navarro Baldeweg denomina "pintura de estratos"».

En el juego de resonancias y ecos especulares que nos propone Ramón Rodríguez Llera, merece mención especial la arquitectura del texto, así como su diseño y maquetación a cargo de Oaestudio. Destaca la elocuencia de las ilustraciones, muchas de ellas de los viajes del autor a Japón y de sus visitas a la obra de Juan Navarro Baldeweg, al igual que la riqueza de notas, pasajes con autonomía propia que actúan como veladuras de información superpuesta, semejantes al papel de la tinta aguada en la pintura sumi-e, por ser discursos paralelos pero no menos complementarios, cuyo calado propicia sugerentes modos de aproximarse a la obra al tiempo que aportan profundidad a la imagen de conjunto.

Iván I. Rincón Borrego Universidad de Valladolid 